Article

\title{
Local Agri-Food Systems as a Cultural Heritage Strategy to Recover the Sustainability of Local Communities. Insights from the Spanish Case
}

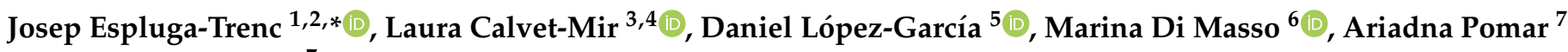 \\ and Guillem Tendero ${ }^{7}$ \\ check for \\ updates \\ 1 Institut de Govern i Polítiques Públiques, Universitat Autònoma de Barcelona, 08193 Bellaterra, Spain \\ 2 Departament de Sociologia, Universitat Autònoma de Barcelona, 08193 Bellaterra, Spain \\ 3 Institut de Ciència i Tecnologia Ambientals, Universitat Autònoma de Barcelona, 08193 Bellaterra, Spain; \\ laura.calvet@uab.cat \\ 4 Internet Interdisciplinary Institute (IN3), Universitat Oberta de Catalunya, 08860 Castelldefels, Spain \\ 5 Fundación Entretantos, 47014 Valladolid, Spain; daniel@entretantos.org \\ 6 Chair Agroecology and Food Systems, University of Vic-Central University of Catalonia, 08500 Vic, Spain; \\ marina.di@uvic.cat \\ 7 Arran de Terra SCCL, 08011 Barcelona, Spain; ariadna@arrandeterra.org (A.P.); \\ guillem@arrandeterra.org (G.T.) \\ * Correspondence: joseplluis.espluga@uab.cat
}

Citation: Espluga-Trenc, J.; Calvet-Mir, L.; López-García, D.; Di Masso, M.; Pomar, A.; Tendero, G. Local Agri-Food Systems as a Cultural Heritage Strategy to Recover the Sustainability of Local

Communities. Insights from the Spanish Case. Sustainability 2021, 13, 6068. https://doi.org/10.3390/ su13116068

Academic Editors: Bart Neuts, João Martins, Milada Št'astná and John Martin

Received: 28 April 2021

Accepted: 25 May 2021

Published: 28 May 2021

Publisher's Note: MDPI stays neutral with regard to jurisdictional claims in published maps and institutional affiliations.

Copyright: (c) 2021 by the authors. Licensee MDPI, Basel, Switzerland. This article is an open access article distributed under the terms and conditions of the Creative Commons Attribution (CC BY) license (https:// creativecommons.org/licenses/by/ $4.0 /)$.

\begin{abstract}
One of the factors threatening the sustainability of rural territories is the hegemonic agroindustrial model, whose environmental and social impacts strongly limit rural life. Here, we want to call attention to the opportunities provided by alternative agri-food systems, based on agroecology and food sovereignty, as a cultural heritage to support sustainable local development. We have carried out exploratory research to draft the main agroecological initiatives in Spain, particularly those having explicit support or encouragement from public administrations. An on-line questionnaire $(n=40)$ was delivered, and in-depth interviews $(n=15)$ were carried out among a sample of people working in the Spanish agroecology sector (public and private). The results demonstrate how the recovery and promotion of traditional ecological knowledge can help to increase the capacity of the social-ecological systems to cope with shocks and disturbances and maintain long-term resilience. In addition, agroecological practices allow collective identities to emerge around the characteristics of the territory strengthening local life, placing the society-ecosystem coevolution at the center of local identity. In conclusion, although still a minority, we have showed how several types of policies conceiving agroecological practices as an intangible collective heritage, with significant transformative potential towards local sustainability, have already been implemented.
\end{abstract}

Keywords: agroecology; traditional ecological knowledge; social identities; rural life

\section{Introduction}

The European rural world is in a precarious situation and requires the implementation of specific policies to guarantee its future sustainability. The promotion of its cultural heritage in all its dimensions can play an important role [1,2]. Available data show that rural, mountainous, and remote areas constitute $80 \%$ of European (EU) territory. These areas are inhabited by $57 \%$ of the EU population and account for $46 \%$ of gross value added [3]. GDP per capita in non-urbanized areas is $70 \%$ of the EU average, while urban residents enjoy a GDP per capita as high as $123 \%$ of the EU average. The European Parliament [3] (p. 1) concludes that "it is important to support rural, mountainous and remote areas in overcoming the challenges they face; whereas one such challenge is rural depopulation, with older people (over 65) representing $20 \%$ of these areas' total population and young people leaving these places; whereas many citizens outside urban areas should 
therefore be given the assurance that they could enjoy similar opportunities to those living in urban areas." The combination of cumulative processes of outmigration and aging, lower educational attainment, lower average labor productivity, and overall low levels of public services constitute serious challenges contributing to a weaker economic performance in rural areas [4]. In addition, we must consider that all these factors can synergize and create a declining circle [5]. The picture becomes worse when we consider the processes of environmental degradation linked to urban and rural development.

Our starting point is the assumption that one factor of most threat to the sustainability of European rural territories is the hegemonic agrarian model developed during the last decades, at least since the 1950's with the advent of the so-called Green Revolution. The application of an industrialized and intensive agricultural model oriented to global markets has led to the prominent ecosystem and social imbalances in the rural world [6-11]. There is agreement among scholars that the European agri-food sector is among the primary drivers of negative environmental externalities. It accounts for more than $10 \%$ of the total greenhouse gas emissions in the EU-28 [12]. The agri-food sector is also among the major contributors to water degradation [13,14] and soil depletion [15], as well as biodiversity loss [16,17]. Agri-food production in the EU also relies on a rapidly aging $(78 \%$ is older than 44 and $31 \%$ older than 65; [18]) and majority-male farming population (women account for less than $32 \%$ of the entire workforce [19]).

However, we also know that rural communities have historically shown high degrees of self-sufficiency, independence, and autonomy, demonstrating resilience and strength through economic downturns, natural disasters, and demographic shifts [20]. Thus, we want to call attention to the opportunities provided by the local agri-food activities. Our aim here is to develop the idea that the land, and activities related to the local agri-food systems, becomes one of the rural world's main assets. We can conceive these assets as an essential heritage for many territories' present and future (although perhaps not all), advocating that we might maintain and promote this heritage through alternative agrarian models such as the agroecology paradigm. This means avoiding the standard practices of industrialized agriculture, which have already demonstrated their wide contribution to the above-mentioned social impacts and environmental harm.

The environmental and socioeconomic crisis of industrialized agriculture has led to the emergence of agroecology as a theoretical and methodological approach aiming to increase agricultural sustainability from an ecological, social, and economic perspective [21]. Agroecology is a theoretical and methodological approach that seeks to increase agricultural sustainability, integrating the natural (e.g., ecology, agronomy, veterinary) and social (e.g., sociology, history, anthropology) sciences. However, the scope of this methodological integration is open for discussion. Some authors consider agroecology as the science that applies ecological concepts and principles to the design and management of sustainable agroecosystems [22], while others conceive it as the way of analyzing all kinds of agricultural processes in a broad sense, in such a way that mineral cycles, energy transformations, biological processes, and socioeconomic relationships are investigated and analyzed as a whole [23]. However, agroecology not only considers how farmers have produced the food (organic, sustainable techniques, environmentally friendly) but also highlights what kind of production relations have been allowed to produce it. The existing relations between the different actors and positions participating in the agri-food system allow the introduction of justice or equity criteria in evaluating the agri-food system's performance and sustainability.

We advocate the inclusion of agroecology in the political framework of food sovereignty to help solve the problems associated with the expansion of the agroindustrial model. Such problems include the socioeconomic and territorial impacts due to a decrease in the agricultural workforce and the correlative rural exoduses, impoverishment, and overpopulation of urban areas, and the political and geopolitical impacts due to the significant redistribution of power in favor of large producers, landowners, and global business corporations [24,25]. Generically, food sovereignty 
implies the right of individuals, communities, peoples, and countries to define their own agricultural, labor, fisheries, food, and land policies in a way ecologically, socially, economically, and culturally appropriate to their unique circumstances [26]. This concept would include the right to food, guaranteed with the correlative right to food production, thus constituting a clear commitment to maintaining and promoting agriculture as the central axis of territorial development.

The overall objective is to show how we can understand certain practices and knowledge related to local agri-food systems as a cultural heritage strategy to support sustainable regional development, and specifically how agroecological practices can function as catalysts for sustainable development at a local scale.

\section{Materials and Methods}

We have developed an exploratory search strategy to identify the main agroecological initiatives in Spain, in particular those having explicit support or encouragement from public administrations. We consider the existence of public policies aimed at local agri-food systems a key turning point with respect to past stages, when agroecological projects were only the object of private initiatives and, therefore, more marginal. Although today these types of policies are still a minority, the fact that a network of local and regional public administrations to promote agroecological policies at territorial level has been put in practice represents a relevant qualitative leap to be considered.

In order to identify the main agroecological policies currently being implemented, we disseminated a small online questionnaire through an intentional sample of people who are working in the field of food and rural development policies in Spain. The open questionnaire was sent to 141 key people who had previously been students on the Postgraduate 'Local Agroecological Dynamization' course at the Autonomous University of Barcelona, of which the authors of this text are the coordinators and teachers. These people have insider views on the topic, as most of them are working in companies, organizations or public administrations related with agroecology. From the 141 people contacted, 40 responded ( 28 women and 12 men, a $28.4 \%$ response rate). In territorial terms, these 40 people resided in 7 different Spanish regions: Catalonia (70\% of the respondents), Valencia (10\%), Basque Country (7.5\%), Castilla-La Mancha (5\%), Madrid (2.5\%), Andalusia $(2.5 \%)$ and Galicia (2.5\%). All were working in the field of agroecology or related food areas, with different job positions: public employees (mainly of municipalities and regional governments) (43\%), private company employees (20\%), employees in NGO or non-profit entities $(12 \%)$, self-employed $(10 \%)$, cooperative members $(8 \%)$, and unemployed $(7 \%)$.

We asked all of them to find out whether they had any direct or indirect knowledge of any agroecological policy or initiative, as well as possible sources to expand details and collect information on its contents. Our aim was to identify and characterize the main political initiatives in this regard in Spain. No significant differences by gender were observed with respect to the information provided. In some cases, exploratory interviews $(n=15)$ were carried out to improve the knowledge on the identified agroecological experiences. This qualitative sample was structured by sector of activity (public/private) and by territorial level (municipality/regional or broader territorial scope).

We were able to define a group of local public policies on agroecological projects. We analyzed these projects conducting a web ethnography (i.e., evaluating the materials available on their respective websites). The analysis was descriptive and thematic since the sole objective was to identify the themes and issues that public administrations were supporting with their policies. We characterized the common traits of the initiatives by using non-predefined categories that emerged from an inductive process [27]. The process consisted of collecting data, looking for patterns and establishing categories not previously defined. These common traits were "support for organic production", "recovery of traditional ecological knowledge and local resources", "promotion of alternative food networks", "the promotion of urban, social, and community gardens"; and "management bodies". We are aware that there are more initiatives in Spain than those listed here, but 
we consider these reflect the main types and include a sufficient variety to illustrate what we intend to argue in this article: the recovery and promotion of agricultural heritage through an agroecological approach can be a key factor when designing sustainable local development strategies.

\section{Results}

In our results, first, we explain some of these initiatives; second, we focus on the policies related to the recovery and promotion of traditional ecological knowledge; and third, we deliberate the potential for agroecological practices to strengthen rural life through the generation of collective identities around local agricultural production. We do so by discussing the results with the related literature.

\subsection{The Emergent Expansion of Agroecological Initiatives in Spain}

The conception of food as cultural heritage capable of revitalizing rural areas, mainly through its combination with tourist activities, has been widely analyzed and has numerous rural development proposals $[28,29]$. Nevertheless, in recent years more and more initiatives for the recovery of local food heritages share agroecological orientations throughout the world [30].

In the Spanish case, although in early times they were promoted mainly by social movements and private initiatives, for a few years (and clearly throughout the penultimate municipal electoral cycle of 2015-2019), regional and local governments are increasingly betting on local food policies [31]. Although still minor, we find several regional and local public administrations working to develop agroecological transition processes in rural areas, focusing on promoting local agri-food heritage as a formula to make local communities more sustainable.

Due to its size and scope, the most crucial initiative we detected is the creation of the General Directorate of Ecological Agriculture in the Andalusia regional government (Junta de Andalucía, 2004-2007). This General Directorate is the only one so far which developed few but prominent programs with an agroecological approach, including the Ecological Agriculture Plans of the Alpujarras and Vega de Granada regions, or the most extensive public food purchase program developed to date, including 150 educational centers and two hospitals directly supplied by a network of more than 70 organic farms and family production cooperatives [32]. More recently (2014-2016), the General Directorate of Commerce of the Junta de Andalucía (regional government) launched the project of "Territorialization of Commerce in Andalusia," which included participatory processes in 18 regions to articulate small businesses, agrarian production and other local actors (not directly linked to the agri-food system, but with capacities to influence it). Both projects had an abrupt end motivated by political changes due to electoral cycles. Even though many processes and projects currently underway draw from these origins, it is difficult to assess their impact on rural development and depopulation in Andalusia due to their lack of continuity.

We identified another case in the Madrid region, where three working groups to promote agroecology were launched in 2016 by the Madrid Institute for Agrarian Research (IMIDRA), together with the regional administration, different local administrations, Local Action Groups of the former LEADER European rural development program, organizations of organic producers and social entities.

In the Valencia region, the project "Municipis en Saó," was launched in 2018 by the Valencian Federation of Municipalities and Provinces and CERAI (NGO working on global justice topics), aimed at training, advising, and accompanying small municipalities in the development of food policies with an agroecological approach.

In the Catalonia region, the "BCN Smart Rural" project was launched in 2018 by the Diputació de Barcelona (local administration) with two other organizations' support. The first one is the Association of Rural Initiatives of Catalonia (ARCA, which represents the territorial Local Action Groups linked to European funds on rural development); and 
the second, the Center of Forestry Science and Technology of Catalonia (CTFC), which includes the start-up of land banks, agroecological incubators, or other actions with an agroecological perspective. This last initiative coincides with, and is reinforced by, creating the "Network of Municipalities for the Food Sovereignty of Central Catalonia," established in 2019 to coordinate a diversity of actors to promote territorial food systems working from an agroecological approach, pooling knowledge and tools to develop them.

In the Basque Country, we identified a project promoted by the EHNE-Bizkaia agricultural union (member of La Vía Campesina, the international organization of peasants) to incorporate young people into agricultural activity from an agroecological and food sovereignty approach. Based on training and support actions for young people, the network of organic food consumption groups "Nekasarea" was created in 2005 and consists of 60 consumer groups and more than 80 producers under a Community Supported Agriculture scheme. Based on this structure, the farmer union and other actors in the Basque Country (such as the "Etxalde" organization, the Emaús Foundation or the UPV's HEGOA Institute) are creating economic structures and networks with an agroecological approach (for example, EH Kolektiboa) and strengthening the articulation of other existing ones (such as Biolur and Ekonekazaritza from organic production). This political advocacy process has achieved numerous municipalities' involvement in promoting local agroecological transitions, such as Zeberio, Orduña, Larrabetxu, and others. As a result of this multi-actor and multi-level process, driven by an agrarian production sector committed to agroecology, it has been possible to observe a reinforcement of organic family productions and agroecological organizations, as well as the creation of agricultural and agri-food employment. We also observed socioeconomic dynamics in some rural territories especially in Bizkaia, but also in Gipuzkoa, and to a lesser extent in other nearer provinces such as Nafarroa and Araba.

All the mentioned processes are characterized by a series of similar practical proposals, as detailed in Table 1. It is not easy to estimate the volume of resources the different public institutions have devoted to promoting all these proposals and measures, although everything seems to indicate that it is a very small, almost marginal, proportion of the budget set usually managed by these institutions. However, what is significant is not the quantity, but the quality, since these are measures that point to a very different development paradigm from that implemented in recent decades. In this sense, it is something unprecedented and that contrasts with the usual trends of public policies for local development.

Regarding their sustainability over time, the very precariousness and provisional nature of these measures seems to be a serious obstacle to their permanence over time. In this regard, some authors who have analyzed some of these political measures [33], warn that without determined and long-term public support they do not have much chance of survival. It is something logical, since they contrast with the vast majority of public policies in the agri-food sector and rural development.

From our perspective, all these actions contribute to reverting some of the territorial, environmental, and social impacts of the agro-industrial model by recovering, protecting, and promoting the local agri-food heritage in a broad sense. In the next two sections we analyze the potential for the recovery of traditional ecological knowledge to energize the local cultural heritage, and the role of agroecological measures in shaping local identities within a sustainability framework. 
Table 1. Common traits among the analyzed local agroecological policies.

\begin{tabular}{|c|c|}
\hline Measures & Details \\
\hline Support for organic production & $\begin{array}{l}\text { Support and training for producers. } \\
\text { Consumer awareness. } \\
\text { Creation of quality local brands. }\end{array}$ \\
\hline $\begin{array}{c}\text { Recovery of traditional } \\
\text { ecological knowledge and local } \\
\text { resources }\end{array}$ & $\begin{array}{l}\text { Constitution of seed banks. } \\
\text { Sales and exchange fairs of landraces. } \\
\text { Promotion of associations of producers of seeds or landraces. } \\
\text { Agreements with local catering sectors to promote local food } \\
\text { consumption. } \\
\text { Creation of land banks to make it available to the local } \\
\text { peasantry (often with public property lands, given the } \\
\text { difficulty of obtaining private lands). } \\
\text { Creation of territorial stewardship initiatives putting } \\
\text { landowners and agroecological producers in contact. }\end{array}$ \\
\hline $\begin{array}{l}\text { Promotion of alternative food } \\
\text { networks }\end{array}$ & $\begin{array}{l}\text { Support for direct sales on the farm, at home or in consumer } \\
\text { groups. } \\
\text { Support for local markets. } \\
\text { Promotion of consumer cooperatives; and/or of joint } \\
\text { cooperatives of organic producers and consumers. } \\
\text { Promotion of collective points of sale of organized organic } \\
\text { producers. } \\
\text { Promotion of alliances between producers and restaurateurs. } \\
\text { Support for stores specialized in local products. } \\
\text { Promotion of collective storage spaces. } \\
\text { Agroecological public purchases (in school canteens, } \\
\text { hospitals, elderly nursing homes). }\end{array}$ \\
\hline $\begin{array}{l}\text { Promotion of urban, social, and } \\
\text { community gardens }\end{array}$ & $\begin{array}{l}\text { Urban gardens become spaces that, beyond self-consumption, } \\
\text { provide relevant functions of leisure, social inclusion, social } \\
\text { and collective empowerment, contact with nature, and } \\
\text { constitute a critical public policy for the recovery of degraded } \\
\text { environments from the social and urbanistic point of view. }\end{array}$ \\
\hline Management bodies & $\begin{array}{l}\text { The application of all these policies requires an organizational } \\
\text { structure in the form of the Municipal Food Council or } \\
\text { administrative units in charge of designing municipal (or } \\
\text { territorial) food strategies, generally with participatory } \\
\text { mechanisms allowing the integration of the various actors of } \\
\text { the local agri-food system. }\end{array}$ \\
\hline
\end{tabular}

\subsection{Agroecology and the Recovery of Traditional Ecological Knowledge}

Agroecology is based on the assumption that each territory has particular agroecosystemic and sociocultural characteristics. Thus, the development of an agri-food model has to align with such features. Unlike the agro-industrial model, which allows and encourages the cultivation of standardized varieties through the intensive and indiscriminate use of chemical inputs, energy, and technology, agroecology seeks to recover landraces culturally adapted to the place in question, as well as traditional cultivation practices, without giving up technological and social innovations that can be incorporated.

Traditional ecological knowledge (TEK) is a cumulative body of knowledge, beliefs, traditions, practices, institutions, and worldviews that have evolved through adaptive processes and are transmitted from generation to generation through cultural transmission [34]. This body of knowledge contains information about the relationships between living beings (including human beings) and their environment [35]. It is based on information coming from a particular cultural group's experience accumulated from generation to generation, socially shared by the community and households, and particular to each individual [36]. TEK's maintenance requires a continuous interaction between the communities and the ecosystems they are part of and healthy and well-connected social networks and insti- 
tutional frameworks $[37,38]$. In this sense, TEK's maintenance can be a critical factor in maintaining social ties at local level and generating cultural traits, that is, knowledge and symbols shared by the community.

Gómez-Baggethun and Reyes-García [38] and Reyes-García [39] suggest TEK has a hybrid and dynamic nature capable of adapting to ecological and socioeconomic changes. According to them, such adaptation is achieved by establishing new forms of knowledge and discarding TEK components that become obsolete or less useful for daily life. The mixture between different bodies of knowledge (scientific and popular-traditional) and the adaptive nature of TEK have been documented in cases where the use of new technologies has gone hand in hand with practices used for centuries in the management of agroecosystems. For example, Riu-Bosoms et al. [40] report a study in the Vall de Gósol (Catalan Pyrenees), where the authors state that due to the increase in local temperature, gardeners realized that the black pea (Pisum sativum L.), a landrace highly appreciated in the area, was affected by the pea weevil (Bruchus pisorum). To protect black peas from the weevil once harvested, gardeners stored them in the freezer for three days to prevent this pest's proliferation. In similar terms, in orchards in north-western Patagonia, Eyssartier et al. [41] observed that market gardeners maintained traditional practices and knowledge when managing home gardens and used modern greenhouses to improve climatic conditions for some crops. In a study with Spanish market gardeners, Reyes-García et al. [39] found that TEK's maintenance was combined with the adoption of modern practices and technologies, i.e., the market gardeners with the highest TEK were those who also had more knowledge about modern practices and technologies. All these studies suggest that TEK is in a continuous adaptation to new biotic situations and socioeconomic changes.

In this same sense, Gómez-Baghetun et al. [37] analyzed the transmission of TEK among local inhabitants in communities linked to protected areas in Doñana (Andalusia). The authors studied the changes in knowledge related to traditional agriculture and livestock practices among 198 informants from three different generations, which covered the period in which Doñana went from having an economy strongly dependent on its natural resources to a market economy with intensive production systems. The inclusion in the market economy led to an abrupt loss of TEK related to agriculture due to rapid transformations and intensification of agricultural systems (basically the conversion of wetlands into highly mechanized rice and strawberry fields, highly dependent on external inputs). However, TEK regarding livestock was better maintained, probably because it is an activity allowed in the protected areas of the natural park of Doñana, and it has maintained strong links with the local cultural identity, such as the well-known week-long "Saca de yeguas" (take out of mares) cattle annual fair. The results show the potential for protected areas to maintain the remnants of TEK in developed countries. However, the authors also point out the fact that a strict environmental protection of the territory can interrupt the long processes of storage and transmission of TEK, since users of local resources and related practices are often excluded from ecosystem management.

Reyes-García [42] shows how TEK has been vital, for example, in the maintenance of the Spanish "dehesas" (wooded meadows), a productive agroecosystem considered as a successful solution between agricultural production and biological conservation, with the simultaneous production of cattle (Iberian pigs, sheep, cows), small and large hunting, firewood, charcoal and eventually cork. The multiple-use management of these wooded meadows (integrating livestock, agriculture, and forestry) configures a characteristic vegetal landscape, fundamentally composed of two plant strata: herbaceous pasture of annual species and trees (holm oak, gall oak, cork oak, and Alvar oak). The author also emphasizes that the intensification and abandonment of the "dehesas" during the last decades can have unforeseen consequences for biodiversity and erode the TEK that sustains them.

Landrace fairs allow us to visualize these traditions and their value. In Morata de Tajuña, a municipality near Madrid, the organization of such a fair made it possible to identify and present the local traditional varieties as an explicit reality. At the beginning, technicians from the local agrarian administration and some farmers denied the existence 
of these traditional seeds and biological varieties, but local farmers proved it [43]. Making it visible is also a way of demonstrating different or complementary paths to the hegemonic agricultural modernization (in this case, the ubiquitous improved seeds) since if those seeds were maintained, it is because they had some value for that community. Showing this alternative reality is a way of broadening the possible future options for the local agri-food system. In this way, traditional ecological knowledge becomes a heritage capable of mobilizing the actors in a more sustainable framework.

Erosion and enclosure (appropriation, patenting, privatization) of TEK threaten its use and reproduction and affect its potential contribution to agroecological transitions. Calvet-Mir et al. [44] explored the extent to which TEK conversion on local varieties into a digital property can contribute to its maintenance and protection. They have analyzed the CONNECT-e platform, an initiative to digitally store and share TEK in a participatory manner. One year after its launch, CONNECT-e documented 452 landraces of 81 different species, and they showed that information shared on the online platform was reliably structured and allowed the replication of reported knowledge by those interested in it. Furthermore, since the platform makes documented information freely available and protected under a copyleft license, placing information on this platform could help address recurring misappropriation issues in this field (i.e., biopiracy) by being included within a digital common framework.

In short, agroecology practices and programs allow the recovery of tangible and intangible heritage, landraces, their management, and their use in a dynamic and integrated way in local life projects, contributing to the viability of sustainable transition processes at territorial level.

\subsection{Agroecology and the Strengthening of Local Identities}

One of the main impacts of the hegemonic agro-industrial food system has been the intense redefinition of agrarian identities, dissociating them from local cultures, which has affected the reconfiguration of the general population's links with their territory. From an individual and symbolic perspective, the agri-food system monopolizes farmers and reduces their importance and their function tends towards the production of agricultural raw materials instead of towards the production of food. The farmer's work also changes radically, having as a leitmotiv the farm's business management, rather than maintaining agriculture understood as a "way of life" [45]. Public policies to support modernization go hand in hand with a substantial "cultural offensive," in which industrialization has manifested itself as a "victory" for professional farmers (those with highly specialized, capitalized, and technical farms), who became the only ones considered real farmers: "the future is conceived as a scarce commodity, and few will survive" [46] (p. 206). Thus, agricultural activity becomes an alienating activity reducing farmer's self-esteem [47] and creating a new peasant's identity which is business-oriented, individualized and dissociated from the local culture and territory.

Agroecology offers ways out of these trends by reducing dependencies on the agroindustrial system, increasing personal and professional empowerment, and the generation of ties with the local social system. For example, in a TEK survey carried out in Morata de Tajuña (Madrid), López García and Guzmán Casado [43] found little local genetic material (only some varieties of fruit trees) but instead obtained fascinating information about traditional management practices with great potential to reinvent sustainable agricultural practices in the municipality. When considering the local agroecological transition, the visibility of these practices had enormous performative potential on the local collective imagination and represented a valuable tool to build the symbolic environment, necessary for the emergence of alternatives to the hegemonic agro-industrial model and reverse its social and environmental impacts.

The demotivation and demobilization of the agricultural sector are some of the main burdens for constructing collective solutions to the problems of the sector. The prominence of traditional ecological knowledge and management lets us advance towards sustainable 
agricultural management, and the agroecological proposal based on multifunctionality ends up including the whole of local society. We might highlight that agroecological transition processes start from the assumption that identifying and activating endogenous resources is something necessary, particularly actors' networks collaborating to launch agroecological projects in the medium or long term. This process requires identifying and networking organic farmers, conventional farmers who may be interested in changing their production model, organized consumer groups, schools, and families of students who may demand organic and proximal food in the school canteens, local shops, restaurants, among other actors. This identification and establishment of connections contribute to generating territorial ties and, therefore, to strengthening local identities around alternative food webs.

Numerous proposals are pushing in this direction, such as the local agroecological revitalization process developed in three districts of Valencia (Spain) [48], intending to revitalize the agrarian social fabric from an agroecological perspective. In this case, promoters followed a methodological scheme of concentric circles, where they incorporated a vision of "marginality" of peri-urban agricultural activity [49]. The central circle involved the creation of groups of farmers to reinforce their leading role in the processes. A second circle agglutinated different social actors in the district (mainly neighborhood associations, cultural groups, educational centers, student family associations, some local shops, and business associations) involved in revitalizing the local socioeconomic fabric from a sustainability perspective. At first, farmers defined their views on their problems (related to mobility problems, crop safety, or degradation of traditional irrigation infrastructures) and the ways to overcome them then the project built processes of cooperation between the first and second circles based on farmers' priorities (see more in Lopez García et al. [48]).

In this process, the construction of meeting spaces (hybrid forums, in the terminology of López-García et al. [50]) between both circles (agrarian actors and extra-agrarian actors from the same territory), based on concrete proposals for action, resulted in the reinforcement of a shared identity linked to the territory. This identity, ultimately, takes shape from the construction of a shared project of alternative and sustainable development for the territory, which includes economic, social, and ecological visions, and which links very different actors excluded by the agro-industrial or corporate food regime [51]. In turn, without the construction of this new shared identity, the promotion of this new model of local development oriented towards the agroecological transition would be more difficult, or perhaps impossible.

\section{Discussion}

We have argued how standard rural development policies are usually subject to global logics derived from the hegemonic agro-industrial model, so it would be convenient to explore alternative models such as those offered by agroecology, by putting land and agricultural activities back at the center of the debate on sustainable rural development.

Agroecological proposals within a food sovereignty frame allow us to think about transition processes towards sustainability at local level, which, as it has been argued in the present text, depends on the recovery of traditional knowledge and the generation of collective identities. Supporting our argument, there is consensus among scholars that TEK favors ecological conservation and biodiversity, generally through a dialogue of knowledge with conservation scientists [52], allowing the reproduction of species through periodic ecosystem closure systems [53] or reducing hunting pressure through taboos [54]. However, it must be said that some studies have documented cases of unsustainable exploitation of natural resources by the local population due to external pressures or increased population density, which have ultimately led to the destruction of habitats and the collapse of these societies $[55,56]$. On the other hand, some authors have also questioned TEK's value for managing natural resources without prior environmental awareness [57]. However, most authors share the idea that TEK increases the capacity of socio-ecological systems to cope with shocks and disturbances, maintain long-term resilience, and, therefore, respond to global environmental change or increase its resilience $[58,59]$. 
It should be taken into account that, following this approach, the recovery of traditional agroecological knowledge does not only consist in resuming the cultivation of certain ancient varieties, but also in mobilizing a collective knowledge linked to the management and use of such products, which inserted in a process with territorial dimensions will contribute to strengthening social ties (or social capital), allowing the emergence of collective identities essential for the development of sustainable projects. Within the agroecological transition, traditional peasant knowledge (as well as its material productions, such as landraces, tools or infrastructures) plays a central role in reconfiguring the symbolic space in which an agrarian society is reproduced, showing a robust performative character of reality $[60,61]$. In this sense, traditional peasant knowledge manages to articulate both symbolic and material rurality components. The idea of rurality still maintains the capacity to generate symbols and references capable of commercializing new 'traditional' products, generating counter-urbanization processes, or mobilizing urban alliances in defense of rural landscapes or certain local foods [62,63].

All these processes advance the agrarian sector's hegemonic identities, opening space for previously unseen alternatives. It is a fact that during the last decades, farmers have built their social and professional identities according to a reduced set of dominant agrarian practices (or styles), where productivity, innovation, and efficiency are important values $[7,64]$. Lockie [65] warns that agri-science is fully embedded in the local knowledge of farmers who survived the green revolution. That is to say, at least during the last halfcentury, there has been a great affinity between farmers and agribusiness, and that this association is important for the construction of the social identity of farmers as efficient professionals and innovators of land. Furthermore, in a pioneering study on the environmental perception of Spanish farmers, Garrido [66] already described the paradoxical situation where the farmer appeared as a polluter and as a victim at the same time. Meanwhile the system encouraged farmers to produce to the maximum and, at the same time, farmers had to act with greater and greater respect for the environment, a requirement which farmers perceived as incompatible with the dominant agricultural practices.

The reconstruction of sociability around the local agrarian heritage makes it possible to place the society-ecosystem coevolution at the local identity center. In this sense, spaces for cooperation based on common goods such as the landscape, TEK, or indigenous seeds, for example, allow collective identities to emerge around the characteristics of the territory, not only among farmers but also among other actors who are part of the local agri-food system (e.g., local shops, restaurateurs, processors, consumers, schools). In this sense, the peasant agrarian heritage can be a motor of the local economy, for example by developing gastronomic routes and alliances with the restaurant, hostel and tourism sectors.

The last decades' depeasantization process has alienated the majority of the population from the local agrarian heritage, even in the rural world. However, the social sectors linked to the hotel industry and local tourism, for example, can reconstruct an innovative vision of local identity based on landrace recovery. Such a blend places the local agrarian tradition within modernity as an element in its own right linked to the local development project. These cases occur with increasing frequency in Spain (see in this regard, for example, López García [67], or the experiences linked to the slow food movement [30], among others).

Finally, the maintenance of the mentioned agroecological initiatives and projects over time will undoubtedly require institutional support in the form of public bodies or territorial dynamization figures capable of convoying the processes. Hence, the appearance of local food councils, participation tables, and the drafting of local food strategies in several parts of Europe, for example, in Spain [68] and the UK [69], among others.

So far, for the Spanish case the institutions most willing to propose alternative local and rural development models are local public administrations (e.g., municipalities, county councils, territorial administrations consortia). The only exception until now is the Junta de Andalucía (regional government), who, despite its limited duration (it ended abruptly due to an electoral change), left fertile soil for the future emergence of new local agroecological initiatives, of a more local size. Perhaps the predominance of local level public 
administrations in the promotion of agroecological initiatives last time, could be attributed to the fact that they are the institutions dealing with the most pressing social problems and potential energy and environmental crises on the horizon. In this sense, the recovery and promotion, or even reinvention, of local cultural heritage, could play a strategic role in moving towards more sustainable rural development.

\section{Conclusions}

Here we have tried to develop the argument that the land and activities related to local agri-food systems can become one of the main rural world's assets. An essential heritage for many territories' present and future (although perhaps not for all) could be promoted through alternative agrarian models such as the agroecology paradigm.

The development of an alternative modernity grounded in agroecology and connected with peasant traits that have survived in the post-industrial rural context, appears as a proposal linked to: short food supply chains and alternative food networks; new agrarian management from an agroecological logic; and the reconstruction of quality concepts adjusted to local cultural features and an alternative to global and impersonal market criteria.

After analyzing some of the most relevant agroecological initiatives that have been carried out in Spain in recent years, we have focused our analysis on two aspects that we consider key to promoting sustainable local development: the recovery of traditional ecological knowledge, a type of knowledge conceived as an intangible collective heritage, and its capacity to strengthen local identities. According to our analysis, peasant agrarian heritage allows farmers to be conceptualized (and presented in society) as people who have historically known how to do something that makes sense, which has been valuable in the past: transforming nature to produce food. With agroecological transition processes, the agrarian prominence in a disaggregated and individualized rural environment becomes an activity that makes sense for a future in which, far from being destined to disappear, can contribute with valuable elements for sustainable local development.

Author Contributions: Conceptualization, J.E.-T., L.C.-M., D.L.-G., M.D.M., A.P. and G.T.; Investigation, J.E.-T., L.C.-M., D.L.-G., M.D.M., A.P. and G.T.; Methodology, J.E.-T., L.C.-M., D.L.-G., M.D.M., A.P. and G.T.; Supervision, J.E.-T.; Writing—original draft, J.E.-T., L.C.-M., D.L.-G., M.D.M., A.P. and G.T.; Writing-review \& editing, J.E.-T., L.C.-M. and M.D.M. All authors have read and agreed to the published version of the manuscript.

Funding: This research received no external funding.

Institutional Review Board Statement: Ethical review and approval were waived for this study, due to the fact that the questions posed to the alumni did not ask any personal information, but only their help in identifying agroecological policies and initiatives in their living environment.

Informed Consent Statement: Informed consent was obtained from all subjects involved in the study.

Data Availability Statement: Data sharing not applicable.

Acknowledgments: Research work for this paper is also part of the academic debates around the postgraduate course on Local Agroecological Dynamization of the Universitat Autònoma de Barcelona.

Conflicts of Interest: The authors declare no conflict of interest.

\section{References}

1. Barthel-Bouchier, D. Cultural Heritage and the Challenge of Sustainability; Routledge: New York, NY, USA, 2016.

2. Pinder, D.; Vallega, A. Coastal cultural heritage and sustainable development: Introduction. J. Cult. Herit. 2003, 4, 3-4. [CrossRef]

3. European Parliament. EU Agenda for Rural, Mountainous and Remote Areas. European Parliament Resolution of 3 October 2018 on Addressing the Specific Needs of Rural, Mountainous and Remote Areas (2018/2720(RSP)). Available online: https: //www.europarl.europa.eu/doceo/document/TA-8-2018-0374_EN.html (accessed on 20 May 2021).

4. WHO Europe. Rural Poverty and Health Systems in the WHO European Region; WHO Regional Office for Europe: Copenhagen, Denmark, 2010. 
5. OECD. The New Rural Paradigm: Policies and Governance; Organisation for Economic Co-Operation and Development: Paris, France, 2006. Available online: http://www.oecd.org/regional/regional-policy/thenewruralparadigmpoliciesandgovernance.htm (accessed on 20 May 2021).

6. Di Masso, M.; Rivera-Ferre, M.G.; Espluga, J. The Transformative Agrifood Movement in Catalonia: Operational Divergences in the Construction of Food Sovereignty. In Alternative Agrifood Movements: Patterns of Convergence and Divergence; Constance, D.H., Renard, M.C., Rivera-Ferre, M.G., Eds.; Emerald: Bingley, UK, 2014; pp. 159-181.

7. Espluga, J. Percepción del riesgo y uso de pesticidas en la agricultura. Ecol. Política 2002, 22, 17-30.

8. Holt-Giménez, E. EEUU: Crisis alimentarias, movimientos alimentario y cambio de regimen. Ecol. Política 2009, $38,73-79$.

9. McMichael, P. Peasants prospects in the neoliberal age. New Political Econ. 2006, 11, 407-418. [CrossRef]

10. Patel, R. Stuffed and Starved; Portobello Books: London, UK, 2007.

11. Rivera-Ferre, M.G. Impacts of Climate Change on Food Availability: Distribution and Exchange of Food. In Global Environmental Change; Freedman, B., Ed.; Volume 1 of the series Handbook of Global Environmental Pollution; Springer: Dordrecht, The Netherlands, 2014; pp. 701-707.

12. European Environment Agency (EEA). Annual European Union Greenhouse Gas Inventory 1990-2016 and Inventory Report 2018 (Report No 5/2018); EEA: Copenhagen, Denmark, 2018.

13. European Environment Agency (EEA). Towards Efficient Use of Water Resources in Europe-No 1/2012; EEA: Copenhagen, Denmark, 2012.

14. Eurostat. Agri-Environmental Indicator-Nitrate Pollution of Water. Available online: http://ec.europa.eu/eurostat/statisticsexplained $/$ index.php?title=Agri-environmental_indicator_-_nitrate_pollution_of_water\&oldid=127703\&printable=yes (accessed on 10 December 2020).

15. Eurostat. Agri-Environmental Indicator-Soil Erosion. Available online: http://ec.europa.eu/eurostat/statistics-explained/ index.php/Agri-environmental_indicator_-_soil_erosion (accessed on 10 December 2020).

16. European Environment Agency (EEA). The European Environment_State and Outlook 2015; EEA: Copenhagen, Denmark, 2015.

17. European Environment Agency (EEA). Environmental Indicator Report 2017 in Support to the Monitoring of the Seventh Environment Action Programme; EEA: Copenhagen, Denmark, 2017.

18. European Commission (EC). The Future of Food and Farming-COM (2017) 713 Final; European Commission: Brussels, Belgium, 2017.

19. Eurostat. Farmers in the EU—Statistics. Available online: http://ec.europa.eu/eurostat/statisticsexplained/index.php/Farmers_ in_the_EU_-_statistics (accessed on 20 May 2021).

20. Fleming, A.R.; Ysasi, N.A.; Harley, D.A.; Bishop, M.L. Resilience and Strengths of Rural Communities. In Disability and Vocational Rehabilitation in Rural Settings; Harley, D., Ysasi, N., Bishop, M., Fleming, A., Eds.; Springer: Cham, Switzerland, 2018 ; pp. 117-136. [CrossRef]

21. Francis, C.; Lieblein, G.; Gliessman, S.; Breland, T.A.; Creamer, N.; Harwood, R.; Salomons-Son, L.; Helenius, J.; Rickert, D.; Salvador, R.; et al. Agroecology: The Ecology of Food Systems. J. Sustain. Agrc. 2003, 22, 99-118. [CrossRef]

22. Gliessman, S.R. Agroecology. In Ecological Processes in Sustainable Agriculture; Ann Arbor Press: Chelsea, MI, USA, 1997.

23. Altieri, M.A. Agroecology. In The Scientific Basis of Alternative Agriculture; Westview Press: Boulder, CO, USA, 1987.

24. Food and Agriculture Organization (FAO). The State of Agricultural Commodity Markets; Trade and Food Security: Achieving a Better Balance between National Priorities and the Collective Good; Food and Agriculture Organization of the United Nations: Rome, Italy, 2015.

25. McMichael, P. The land grab and corporate food regime restructuring. J. Peasant. Stud. 2012, 39, 681-701. [CrossRef]

26. La Vía Campesina. Soberanía Alimentaria, un Futuro sin Hambre. Declaracion de Roma. 1996. Available online: https: / / nyeleni.org/spip.php?article38 (accessed on 20 May 2021).

27. Newing, H. Conducting Research in Conservation: Social Science Methods and Practice; Routledge: London, UK, 2011.

28. Bessière, J. Local development and heritage: Traditional food and cuisine as tourist attractions in rural areas. Sociol. Rural. 1998, 38, 21-34. [CrossRef]

29. Aleffi, C.; Cavicchi, A. The Role of Food and Culinary Heritage for Postdisaster Recovery: The Case of Earthquake in the Marche Region (Italy). J. Gastron. Tour. 2020, 4, 113-128. [CrossRef]

30. Grimaldi, P.; Fassino, G.; Porporato, D. (Eds.) Culture, Heritage, Identity and Food. A Methodological Approach; Interreg Central Europe SlowFood-CE. Francoangeli: San Giuliano, Italy, 2019.

31. Vicente-Almazán, L.; Herrera, M.; Escobar, M. (Eds.) Sistemas Alimentarios Territorializados en España. 100 Iniciativas Locales Para una Alimentación Responsable y Sostenible; CERAI and Fundación Daniel \& Nina Carasso: Valencia, Spain, 2019.

32. González de Molina, M. (Ed.) El desarrollo de la agricultura ecológica en Andalucía (2004-2007); Crónica de una Experiencia Agroecológica: Icària, Greece, 2009.

33. González de Molina, M. Luces y sombras del crecimiento de la producción ecológica en Andalucía durante el último quinquenio (2007-2011). Cuad. Interdiscip. Desarro. Sosten. 2012, 9, 153-191.

34. Berkes, F.; Colding, J.; Folke, C. Rediscovery of traditional ecological knowledge as adaptive management. Ecol. Appl. 2000, 10, 1251-1262. [CrossRef]

35. Berkes, F. Traditional Ecological Knowledge in perspective. In Traditional Ecological Knowledge: Concepts and Cases; Inglis, J.T., Ed.; International Program on Traditional Ecological Knowledge: Ottawa, ON, Canada, 2014; pp. 1-6. 
36. Toledo, V. Ethnoecology: A conceptual framework for the study of indigenous knowledge of nature. In Ethnobiology and Biocultural Diversity; International Society of Ethnobiology: Gainesville, FL, USA, 2002; pp. 511-522.

37. Gómez-Baggethun, E.; Mingorría, S.; Reyes-Garcia, V.; Calvet-Mir, L.; Montes, C. Traditional Ecological Knowledge Trends in the Transition to a Market Economy: Empirical Study in the Doñana Natural Areas. Conserv. Biol. 2010, 24, 721-729. [CrossRef] [PubMed]

38. Gómez-Baggethun, E.; Reyes-García, V. Reinterpreting change in traditional ecological knowledge. Hum. Ecol. Interdiscip. J. 2013, 41, 643-647. [CrossRef] [PubMed]

39. Reyes-García, V. The Values of Traditional Ecological Knowledge. In Handbook of Ecological Economics; Martinez-Alier, J., Muradian, R., Eds.; Edward Elgar: Cheltenham, UK, 2014.

40. Riu-Bosoms, C.; Calvet-Mir, L.; Reyes-García, V. Factors enhancing landrace in situ conservation in home gardens and fields in Vall de Gósol, Catalan Pyrenees, Iberian Peninsula. J. Ethnobiol. 2014, 34, 175-194. [CrossRef]

41. Eyssartier, C.; Ladio, A.H.; Lozada, M. Horticultural and Gathering Practices Complement Each Other: A Case Study in a Rural Population of Northwestern Patagonia. Ecol. Food Nutr. 2011, 50, 429-451. [CrossRef] [PubMed]

42. Reyes-García, V. Conocimiento ecológico tradicional para la conservación: Dinámicas y conflictos. Pap. Relac. Ecosociales Cambio Glob. 2009, 107, 39-55.

43. López García, D.; Guzmán Casado, G.I. Si la tierra tiene sazón. El conocimiento tradicional campesino como movilizador de procesos de transición agroecológica. Agroecología 2013, 7, 7-20.

44. Calvet-Mir, L.; Benyei, P.; Aceituno-Mata, L.; Pardo-De-Santayana, M.; López-García, D.; Carrascosa-García, M.; PerdomoMolina, A.; Reyes-García, V. The Contribution of Traditional Agroecological Knowledge as a Digital Commons to Agroecological Transitions: The Case of the CONECT-e Platform. Sustainability 2018, 10, 3214. [CrossRef]

45. Gallar, D. La Construcción de la Universidad Rural Paulo Freire. Culturalismo Para una Nueva Ruralidad Campesinista. Ph.D. Thesis, Universidad de Córdoba, Córdoba, Spain, 2011.

46. Ploeg, J.D. Nuevos Campesinos; Campesinos e Imperios Alimentarios: Icaria, Greece; Barcelona, Spain, 2010.

47. Sánchez de Puerta, F.; Taberner, J.B. Innovación y alienación en la agricultura: Una perspectiva socioecològica. Agric. Soc. 1995, 74, 159-177.

48. López-García, D.; Benlloch Calvo, L.; Calabuig Tormo, V.; Carucci, P.; Díaz Torrijos, I.; Herrero Garcés, A.; López Nicolás, M.; Pérez Sánchez, J.M.; Vicente-Almazán, L. Las transiciones hacia la sostenibilidad como procesos de final abierto. Dinamización Local Agroecológica con horticultores convencionales de l'Horta de València. Boletín Asoc. Geógrafos Españoles 2020, 88. [CrossRef]

49. Paül, V. Agricultural marginality and marginal agriculture in metropolitan areas. A proposal for systematisation based on some Spanish case-studies. In Issues on Geographical Marginality; Jones., G., Leimgruber, W., Nel, E., Eds.; Rhodes University: Grahamstown, South Africa, 2007; pp. 38-46.

50. López-García, D.; Calvet-Mir, L.; Di Masso, M.; Espluga, J. Multi-actor networks and innovation niches: University training for local Agroecological Dynamization. Agric. Hum. Values 2019, 36, 567-579. [CrossRef]

51. McMichael, P. Regímenes Alimentarios y Cuestiones Agrarias; Icària: Barcelona, Spain, 2016.

52. Moller, H.; Berkes, F.; Lyver, O.; Kislalioglu, M. Combining Science and Traditional Ecological Knowledge: Monitoring Populations for Co-Management. Ecol. Soc. 2004, 9, 2. [CrossRef]

53. Cinner, J.; Marnane, M.J.; Mcclanahan, T.R.; Almany, G.R. Periodic closures as adaptive coral reef management in the Indo-Pacific. Ecol. Soc. 2005, 11, 31. [CrossRef]

54. Puri, R.K. Deadly Dances in the Bornean Rainforest: Hunting Knowledge of the Penan Benalui; KITLV Press: Leiden, The Netherlands, 2005.

55. Henrich, J. Demography and cultural evolution: How adaptive cultural processes can produce maladaptive losses-The Tasmanian case. Am. Antiq. 2004, 69, 197-214. [CrossRef]

56. Diamond, J. Collapse: How Societies Choose to Fail or Succeed; Viking Press: New York, NY, USA, 2005.

57. Smith, A.; Wishnie, M. Conservation and subsistence in small-scale societies. Annu. Rev. Anthropol. 2000, 29, 493-524. [CrossRef]

58. Berkes, F.; Turner, N.J. Knowledge, learning and the evolution of conservation practice for social-ecological system resilience. Hum. Ecol. Interdiscip. J. 2006, 34, 479-494. [CrossRef]

59. Turnhout, E.; Bloomfield, B.; Hulme, M.; Vogel, J.; Wynne, B. Conservation policy: Listen to the voices of experience. Nature 2012, 488, 454-455. [CrossRef]

60. Dirksmeier, P.; Helbrecht, I. Time, non-representational theory and the 'performative turn'-Towards a new methodology in qualitative social research. Forum Qual. Soz. 2008, 9, 1-15. [CrossRef]

61. Daniel, J.F. Action Research and Performativity: How Sociology Shaped a Farmers' Movement in The Netherlands. Sociol. Rural. 2011, 51, 17-34. [CrossRef]

62. Reed, M. The rural arena: The diversity of protest in rural England. J. Rural. Stud. 2008, 24, 209-218. [CrossRef]

63. López García, D. Canales cortos de comercialización como elemento dinamizador de las agriculturas ecológicas urbana y periurbana. In Proceedings of the Actas del I Congreso Estatal de Agricultura Ecológica Urbana y Periurbana, Elche, Spain, 6-7 May 2011.

64. Espluga, J. La exposición laboral a pesticidas en la agricultura. Un caso de aparente subestimación del riesgo. Sociol. Trab. 2004, $51,33-60$.

65. Lockie, S. Chemical Risk and the Self-Calculating Farmer: Diffuse Chemical Use in Australian Broadacre Farming Systems. Curr. Sociol. 1997, 3, 81-97. [CrossRef] 
66. Garrido, F. Análisis de los Discursos, Actitudes y Estrategias de los Agricultores y sus Organizaciones Profesionales ante la Introducción de Métodos de Desarrollo Sostenible en la Agricultura Europea. Ph.D. Thesis, Universidad de Córdoba, Córdoba, Spain, 1999.

67. López García, D. Producir Alimentos, Reproducir Comunidad. In Redes Alimentarias Alternativas como Formas Económicas para la Transformación Social y Ecológica; Libros en Acción: Madrid, Spain, 2015.

68. Espluga, J.; Di Masso, M.; López García, D. Agroecologia i polítiques per la sobirania alimentària: Fórmules per afrontar la triple crisi energètica, ambiental i econòmica. In Canvi D'època i de Polítiques Publiques a Catalunya; Gomà, R., Subirats, J., Eds.; Galaxia Guttenberg: Barcelona, Spain, 2019; pp. 144-159.

69. Moragues-Faus, A. Towards a critical governance framework: Unveiling the political and justice dimensions of urban food partnerships. Geogr. J. 2020, 186, 73-86. [CrossRef] 